\title{
Analysing the Short-run and Long-run Relationships between Macroeconomic Variables and Financial Development in Jordan From $1978-2013$
}

\section{Salem Mohammad}

Department of Accounting and Finance, College of Administrative Sciences, Jordanian

*Corresponding author: Salem Mohammad, Department of Accounting and Finance, College of Administrative Sciences, Jordanian, Tel: 0175428587; E-mail: mustafadakian@gmail.com

Rec date: June 15, 2017; Acc date: June 30, 2017; Pub date: July 7, 2017

Copyright: () 2017 Mohammad S. This is an open-access article distributed under the terms of the Creative Commons Attribution License, which permits unrestricted use, distribution, and reproduction in any medium, provided the original author and source are credited.

\begin{abstract}
The main objective of this study was to examine the short and long-run relationships between macroeconomic variables such as : gross domestic product, foreign direct investment, money supply, consumer price index, interest payment on external debt and fuel import and Jordan's financial development represented by Amman Stock Exchange (ASE), Conventional Banking System (CBS) and Islamic Banking System (IBS). Moreover; to examine the directional causality between Jordanian economy and financial development. The annual time series data for the period from 1978 to 2013 is used to obtain these objectives. The Granger Causality Test revealed a unidirectional causality relationship between economic growth and Jordan's financial development. Also, the economic growth appear to lead the ASE while, CBS and IBS appear to lead the economic growth. These results are in support of the theories and the hypotheses of this study which postulates that the financial development were positively affected by GDP, FDI, MS2 and F1 and negatively affected by CPI and IP is the short and long-run analysis. Further, the macroeconomic variables appeared to strongly predict Jordanian financial development performance. Jordan's government and policy-makers should encourage the investors to establish more Islamic banks, launch awareness campaigns and financial market's programs, and continue governing the monetary policy in the right direction to combat inflation. Future studies may focus on the influence of other variables such as: the privatisation programs, total debt, public and private domestic savings and economic openness on Jordan's financial development.
\end{abstract}

Keywords Macroeconomic variables; Conventional banking system (CBS); Islamic banking system (IBS); Economic growth; Financial development

\section{Overview}

The official name of Jordan is the Hashemite Kingdom of Jordan and it is situated in the central part of the Middle East with the area span of 89,342 sq. Km. Its borders the east of Palestine, the southeast of Iraq, northwest of Saudi Arabia, and the south of Syria. Jordon has access to the Red sea through the port city of Aqaba, which is located at the northern end of the Gulf of Aqaba [1]. There are four (4) important periods of Jordan's economy and each is summarised as follows:

\section{First period (1976-1981)}

During this first period, Jordan had applied the Five-year Development Plan and as a result, Jordan achieved a period of economic prosperity. This was evidenced by Jordan's GDP record's growth sales, where the average annual growth rate in GDP at current prices was at $20.7 \%$, while the average annual growth rate in GDP was at consistent prices (14.4\%). This economic boom as witnessed during this period occurred owing to several factors where the most significant was the rise of oil prices in the world market. These price rises have led the increase in the financial surpluses of oil producing countries and increase in the development spending as well as the increase in the demand for Jordanian labour in the Gulf countries, and these consistently increase the workers' remittances of Jordanians abroad. Additionally, these also contributed to increase in spending and income in these countries as they were compelled to increase demand for Jordan exports.

\section{Second period (1982-1988)}

On during this period, Jordan experienced decline in economic activities with the average annual growth rate in GDP at the current and fixed prices of $7.3 \%$ and $2.2 \%$ respectively. This decline was a natural result of the beginning of the regional and global economic recession period. In the same time, Jordan suffered severe economic crisis at the end of the stage and this was characterised by budget deficit and payment's deficit balance at high levels, falling Jordian's foreign currency reserves and the worsening situation of foreign debt. All of these factors have put the price of Jordanian dinar under pressure where it fell from USD $\$ 2.95$ in 1982 to USD\$1.73 in 1989. This period also coincided with the implementation the second FiveYear Development Plan (1981-1985) and the third Five-Year Development Plan (1986-1990).

\section{Third period (1989-1998)}

The third period of Jordan's economy is known as the reform period. This period was marked by the subsequent financial crises and severe economic condition faced by the Kingdom in the late 1988. This was represented by the worsening dinar exchange rate and the situation of foreign debt. Thus, in April 1989, Jordan had implemented a structural adjustment program for the period of 1989-1993. However, this program was stalled for more than 15 months due to the vulnerability 
of the country following the second Gulf War crisis. Nevertheless, Jordan's negotiations were resumed to conclude an agreement of structural adjustment program of a new period (1992-1998) in order to manage the external debt crisis, to restore internal and external fiscal balance and to rectify the accumulated imbalances over the previous years.

\section{Fourth period (1999-present)}

This is the transformation period for Jordan and more importantly, this is also the period of when King Abdullah II bin Al Hussien received his constitutional powers in 1999, which become a highlight in the economic and social reform priorities. His Majesty drew his government in October 2001 to adopt the economic and social transformation program during the period of 2002-2004, and in parallel with us, Jordan adopted the new Five-Year Development Plan for the period of 1999-2003. Both of these were aimed at speeding up the economic policies and programs implementation to improve the living standard of the citizens by continuing to thrive in the liberalisation of the economy. Further, these program and development plan were implemented to attract more Arab and foreign investments, and to promote the private sectors' role and participation in investment in development projects and major development and work to address the poverty and unemployment problems.

During this stage, Jordan also adopted two economy corrections programs, of which the first one was during the period of 1999-2001. In particular, the primary objectives of this program were to increase real growth rate, sustain low level of inflation, stimulate reserves of foreign exchange, decrease the external debt's outstanding balance, and decrease poverty and unemployment issues. Then, the second program was adopted in June 2002. This program was implemented to continue privatisation programs in Jordan and also to continue economic openness in preparation for the merger with the Arab economy and the world to strengthen the foreign exchange reserves and to reduce the outstanding balance of external debt. The task was completed in June 2004.

In additional, this period contains another plan for the economic and social development and this was during the 2004-2006 period, where the focus was on the sustainability of financial stability, monetary stability and the stability of the dinar exchange rate. Further, the focus of the plan was also on ensuring the stability of goods and services prices, activating the partnership between the public and private sectors, ensuring the promotion of the private sectors's role as the/a major participant in the development of economy activity, achieving a quantum leap in the performance of national economy, creating a significant change in the quality and standard of living and reducing poverty and unemployment problems. The outcomes of all these were reflected in the achievement of Jordan's economy that is characterised by high growth rates during this period which averaged about $9.0 \%$ and $6.3 \%$ at current and fixed price respectively.

\section{Problem Statement and Objectives of Research}

The perspective of trade liberalisation, Jordan is characterised as an open economy. The country is well integrated with its neighbours through trade, remittances, FDI and tourism ties. Therefore, the country has been exposed to political, economic and social volatility in the region especially during the Arab Spring, which began at the end of 2010 [2]. During this period, the refugees fled from Iraq, Syria and other countries, straining Jordan's economy, and raising the price of goods. In additional, Jordan's lack of sufficient natural resources, such as water, oil and gas, tends to exacerbate the economic situation as those resources are imported from other countries [3].

One of the main factors that drive Jordan's economic growth is its financial market [4]. Additionally, due to the current political situation (the Arab Spring) which surrounded Jordan, several macroeconomic variables have increased dramatically in the recent years such as, CPI as a proxy of inflation, unemployment rate (UR), oil price and other macroeconomic variables. For instance, the annual growth rate of CPI for the period of 1978-2012 reached approximately 5\%, while the annual growth rate of the Malaysia CPI was 2.8\% and for Saudi Arabia is was only $1 \%$ for the same period. However, the Central Bank of Jordan Report 2013 showed that the inflation reached 5.6\% in 2013. As for Jordan's unemployment rate, the annual growth rate was $0.06 \%$ and for Malaysia and Saudi Arabia it was $-3.1 \%$ and $-1 \%$ respectively, for the period of 1987-2012.

This study was tackles a short comparison between Malaysia, Saudi Arabia and Jordan in this case since these countries are developing countries; they have political stability situations and established the first Islamic Banks and stock market during the same period. It should be noted that unlike Jordan, the Islamic Banks, stock markets and political stability situations are almost non-existent in some Arab countries such as Iraq, Syria and Palestine to be included in this comparison. On the other hand, the success of the Malaysian economy is one of the best examples in economic aspects for the developing countries.

The impact of macroeconomic variables on the financial market is clearly shown in the ASEI performance that there were some remarkable decreases in 2011 and 2012 (4,648 and 4,593.9 points) respectively. Meanwhile, the annual growth rate of Jordan's domestic credit provided by banking sector was $1.08 \%$ while for Malaysia, it was $1.14 \%$ for the period between 1980-2012. The uncertainty and instability of the macroeconomic variables and financial markets have made the investors and decision markers hesitant and worried about investing in Jordan's market. The present study focuses in assessing the performance of the capital and credit markets by detecting the most important macroeconomic factors that have the greatest impact in the analysis of market indicates that assist investors in making a right decision and encourage investment to help spur the growth of Jordan's economy.

The objective of this study is to examine the impact of selected macroeconomic variables namely; gross domestic product, foreign direct investment, money supply, consumer price index, interest payment on external debt and fuel import on the Amman Stock Exchange and to measure the effect of these variables on the Conventional Banking System and Islamic Banking System in Jordan.

More specifically, this study seeks to achieve the following subobjectives:

To examine the short and long-run relationship between macroeconomic variables namely; GDP, FDI, MS2, CPI, IP and FI, and Amman Stock Exchange (ASE), Convenional Banking System (CBS) and Islamic Banking System (CBS).

To examine the relationships between global events (dummy variables - September 11, 2001, the Iraqi War and Global Financial Crisis and the Arab Spring) and the ASE, CBS and IBS.

To examine the directional Granger causality between Jordan's economy and ASE, CBS and IBS. 
Citation: Mohammad (2017) Analysing the Short-run and Long-run Relationships between Macroeconomic Variables and Financial Development in Jordan From 1978-2013. J Glob Econ 5: 253. doi:10.4172/2375-4389.1000253

Page 3 of 9

To outline policy recommendations for the financial development and macroeconomic variables in Jordan perspective.

\section{Research Design}

The study used the annual time series data for the period of 1978 -2013 with a sample size of 36 observations. It is difficult to use other data forms such as the monthly, quarterly and semi-annual data aside from the annual data due to the availability of the study data. Furthermore, the study period is selected based on two reasons. Firstly, the ASE and the first Islamic Bank were established in 1978. Secondly, the study attempts to cover the period that contains the highest amount of crises and events that happened both globally and in the region, which also had affected Jordan economy. The ASE data were obtained from the ASE database, while the Islamic bank data were obtained from the Annual Reports (printed copy) of Jordan Islamic Bank and the conventional banks, whereas the macroeconomic variables data were obtained from the publications and databases of the World Bank and Central Bank of Jordan. The study selected some macroeconomic variables according to the availability of data on these variables in the economy of Jordan because the macroeconomic variables are the important indicators of the economic growth of a give country.

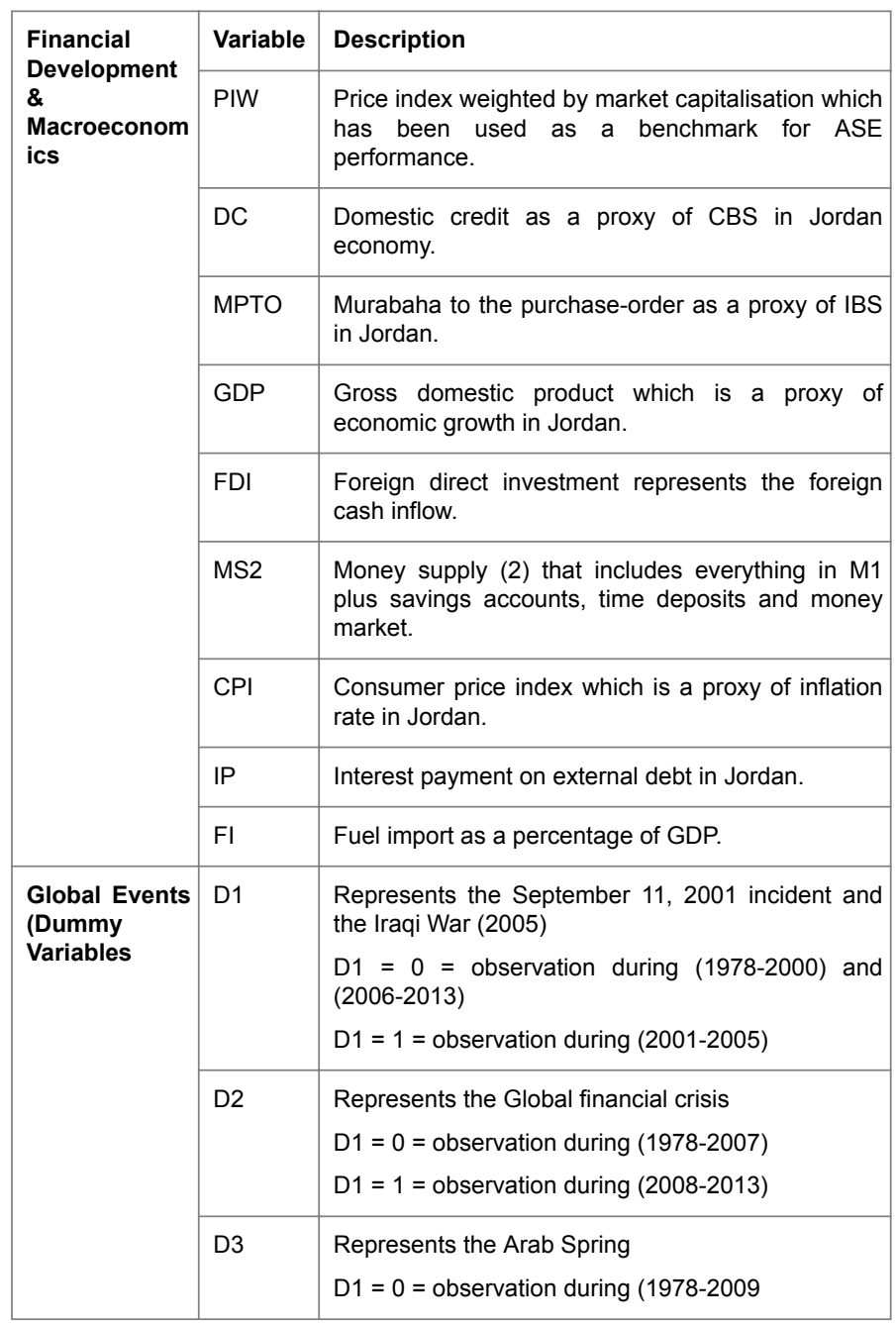

\begin{tabular}{|l|l|l|}
\hline & D1 =1 = observation during (2010-2013) \\
\hline
\end{tabular}

Table 1: Descriptions of Current Study.

Table 1 comprises of the variable descriptions that the current study is employed. These variable descriptions are classed into the financial market variables which are denoted by PIW, DC and MPTO. Meanwhile, the macroeconomic variables are denoted by GDP, FDI, MS2, CPI, IP and FI, whereas the global events are denoted by D1, D2 and D3.

There are numerous theories that could be employed in describing the linkage between financial development and the set of economy from varying perspectives. Additionally, empirical studies which conclude strong linkage between the stock market, the financial intermediaries' development and the economic expansion are growing in number. Levine is amongst those outstanding scholars in scrutinising the financial development and economic growth [5]. Levine has confirmed the existence of communications between stock markets and banks during the course of economic development. Diagram 1 explains the relationship between Jordan's financial development and macroeconomic variables by using the appropriate theories that were adopted to examine the relationships.

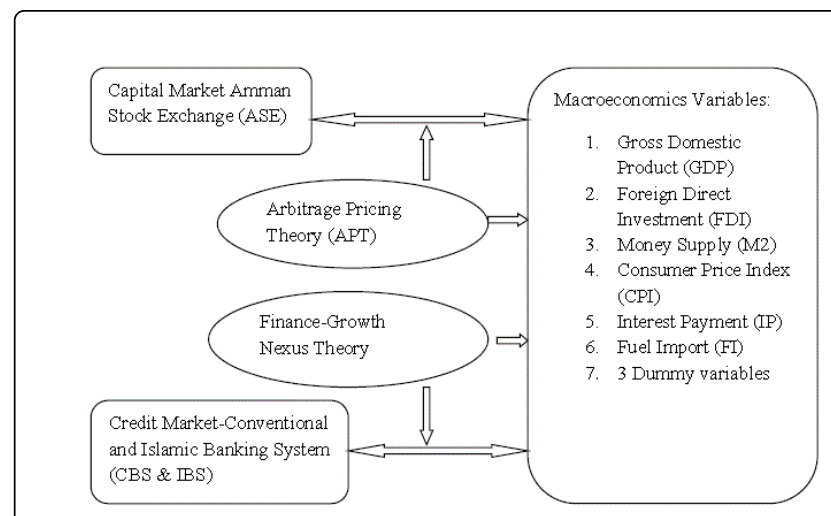

Figure 1 : Jordan's Financial System and Theoretical Framework

Different theories have illustrated the relationship between the financial development and the macroeconomic variables. In particular, the relationship between financial development and economic growth was highlighted by Schumpeter (1911). Meanwhile, the relationship between stock market and the macroeconomic variables was explained by FAMA (1981). The current study relies on the Arbitrage Pricing Theory (APT) because APT links the capital market with the macroeconomic variables. Meanwhile, to clarify the relationship between the macroeconomics variables and the credit market, the finance-growth nexus theory is employed. The objective of study is to examine the relationship between Jordan's financial market and the macroeconomic variables such as LASE, LCBS and LIBS on the macroeconomic variables are formulated based on the models below:

The ASE Model:

$\mathrm{LPIWt}=\mathrm{Yo}+\mathrm{Y} 1 \mathrm{LGDPt}+\mathrm{Y} 2 \mathrm{LFDIt}+\mathrm{Y} 3 \mathrm{LMS2t}+\mathrm{Y} 4 \mathrm{LCIPt}+\mathrm{Y} 5 \mathrm{LIPt}$ $+\mathrm{Y} 6 \mathrm{FIt}+\mathrm{Y} 7 \mathrm{D} 1 \mathrm{t}+\mathrm{Y} 8 \mathrm{D} 2 \mathrm{t}+\quad \mathrm{Y9D} 3 \mathrm{t}+$

The CBS Model: 
Citation: Mohammad (2017) Analysing the Short-run and Long-run Relationships between Macroeconomic Variables and Financial Development in Jordan From 1978-2013. J Glob Econ 5: 253. doi:10.4172/2375-4389.1000253

Page 4 of 9

$\mathrm{LDCt}=\mathrm{Yo}+\mathrm{Y} 1 \mathrm{LGDPt}+\mathrm{Y} 2 \mathrm{LFDIt}+\mathrm{Y} 3 \mathrm{LMS} 2 \mathrm{t}+\mathrm{Y} 4 \mathrm{LCIPt}+\mathrm{Y} 5 \mathrm{LIPt}+\mathrm{Y} 6 \mathrm{FIt}$ $+Y 7 D 1 t+Y 8 D 2 t+Y 9 D 3 t+$

The IBS Model:

$\mathrm{LMTPOt}=$ Yo+Y1LGDPt+Y2LFDIt+Y3LMS2t+Y4LCIPt+Y5LIPt $+Y 6 F I t+Y 7 D 1 t+Y 8 D 2 t+Y 9 D 3 t+$

These models illustrate the general relationship between Jordan's financial development (ASE, CBS and IBS) and its determined variables, where Yo is the constant term; Y1....Y9 are the coefficients of the models; $t$ represents time and $\varepsilon 1$ represent error term.

\section{Discussion on the Finding}

\section{Causality analysis}

As can be seen in the preceding section, the short-run as well as the long-run relationships between the macroeconomic variables and the financial development have been analysed using the ARDL approach. Then, in the situation where the ARDL approach in analysing the longrun relationship does not display the relationship direction, the Granger causality will be used instead. In particular, the Granger causality test could decide the relationships direction between variables. Additionally, the Granger causality test can also be employed when researcher wants to ascertain which variable that has the leading power over the other(s). The Granger causality test outcomes for the three modelsof ASE, CBS and IBS are presented in Tables 2, 3 and 4.

\section{Granger-causality results for the first model - amman stock exchange (ase)}

Table 2 presents the ASE model's Granger causality test results. Here, the model variables' $p$-values are used to indicate the acceptance or rejection of the null hypothesis. As shown by the Table, $\Delta \mathrm{LGDPt}$ Granger causes $\Delta$ LPIWt in a unidirectional relationship. This implies that the null hypothesis (H0) can be rejected. Additionally, $\triangle \mathrm{LMS} 2 \mathrm{t}, \Delta \mathrm{LCPIt}$ and $\Delta \mathrm{LIPt}$ appear to possess the leading power to the $\Delta$ LPIWt in Jordan in a unidirectional relationship. Meanwhile, $\Delta$ LFDIt displays a bi-directional causality with $\Delta$ LPIWt. However for $\Delta$ FIt, the results suggest that the null hypothesis cannot be rejected. This implies that based on their p-values, the $\Delta$ LPIWt does not Granger cause the $\Delta$ FIt variable or vice versa.

In term of the independent variables, the results suggest that there is a bi-directional Granger causality between $\triangle$ LGDPt and $\triangle$ LFDIt. However, the results show that $\triangle$ LMS2tand $\triangle$ LCPIt Granger cause $\Delta \mathrm{LGDPt}$ in a unidirectional way. On the other hand, $\Delta \mathrm{LGDPt}$ Granger causes $\Delta$ FIt in a unidirectional manner.

As for $\Delta$ LMS2t model, it appears that $\Delta$ LMS2t Granger causes $\Delta$ LFDIt in a unidirectional way. The results obtained for the $\Delta$ LCPIt model suggest that, $\triangle$ LCPIt only Granger causes $\Delta$ LFDIt but not vice-versa. Further, the $\Delta$ LIPt model appears to lead the $\Delta$ LMS2t in a unidirectional way but the same cannot be said for the opposite. The causal relationship between $\Delta$ FIt and the other variables is also demonstrated in Table 2 and as proven by the results, $\Delta$ FIt has no leading power towards the variables.

\begin{tabular}{|l|l|l|l|}
\hline Causality Direction & $\begin{array}{l}\text { F- } \\
\text { Statistic }\end{array}$ & P-value & Causality Decision \\
\hline
\end{tabular}

\begin{tabular}{|c|c|c|c|}
\hline$\Delta \mathrm{LGDP}_{\mathrm{t}} \rightarrow \Delta \mathrm{L} \mathrm{PIW}_{\mathrm{t}}$ & 11.0257 & 0.0023 & $\begin{array}{l}\text { Unidirectional } \\
\text { Causality }\end{array}$ \\
\hline$\Delta \mathrm{LPIW}_{\mathrm{t}} \neq \Delta \mathrm{LGDP}_{\mathrm{t}}$ & 1.54741 & 0.2226 & No Causality \\
\hline$\Delta$ LFDIt $\rightarrow \Delta$ LPIWt & 4.03848 & 0.053 & \multirow[t]{2}{*}{ Bidirectional Causality } \\
\hline$\Delta \mathrm{LPIWt} \rightarrow \Delta \mathrm{LFDIt}$ & 3.53171 & 0.0693 & \\
\hline$\Delta \mathrm{LMS} 2 \mathrm{t} \rightarrow \Delta \mathrm{LPIWt}$ & 4.14074 & 0.0502 & $\begin{array}{l}\text { Unidirectional } \\
\text { Causality }\end{array}$ \\
\hline$\Delta \mathrm{LPIWt} \neq \Delta \mathrm{LMS} 2 \mathrm{t}$ & $7.9 \mathrm{E}-06$ & 0.9978 & No Causality \\
\hline$\Delta \mathrm{LCPIt} \rightarrow \Delta \mathrm{LPIWt}$ & 3.07035 & 0.0365 & $\begin{array}{l}\text { Unidirectional } \\
\text { Causality }\end{array}$ \\
\hline$\Delta \mathrm{LPIWt} \neq \Delta \mathrm{LCPIt}$ & 0.74780 & 0.5695 & No Causality \\
\hline$\Delta \mathrm{LIPt} \rightarrow \Delta \mathrm{LPIWt}$ & 4.76527 & 0.0365 & $\begin{array}{l}\text { Unidirectional } \\
\text { Causality }\end{array}$ \\
\hline$\Delta \mathrm{LPIWt} \neq \Delta \mathrm{LIPt}$ & 0.72469 & 0.4009 & No Causality \\
\hline$\Delta \mathrm{LFDIt} \rightarrow \Delta \mathrm{LGDP}_{\mathrm{t}}$ & 4.55933 & 0.0405 & \multirow[t]{2}{*}{ Bidirectional Causality } \\
\hline$\Delta \mathrm{LGDP}_{\mathrm{t}} \rightarrow \Delta \mathrm{LFDI}_{\mathrm{t}}$ & 4.84895 & 0.035 & \\
\hline$\Delta \mathrm{LMS}_{\mathrm{t}} \rightarrow \Delta \mathrm{LGDP}_{\mathrm{t}}$ & 3.96674 & 0.055 & $\begin{array}{l}\text { Unidirectional } \\
\text { Causality }\end{array}$ \\
\hline$\Delta \mathrm{LGDP}_{\mathrm{t}} \neq \Delta \mathrm{LMS}_{\mathrm{t}}$ & 1.48625 & 0.2317 & No Causality \\
\hline$\Delta \mathrm{LCPI}_{\mathrm{t}} \rightarrow \Delta \mathrm{LGDP}_{\mathrm{t}}$ & 3.58484 & 0.0674 & $\begin{array}{l}\text { Unidirectional } \\
\text { Causality }\end{array}$ \\
\hline$\Delta \mathrm{LGDP}_{\mathrm{t}} \neq \Delta \mathrm{LCPI}_{\mathrm{t}}$ & 0.63678 & 0.4308 & No Causality \\
\hline$\Delta \mathrm{FI}_{\mathrm{t}} \neq \Delta \mathrm{LGDP}_{\mathrm{t}}$ & 0.21454 & 0.6464 & No Causality \\
\hline$\Delta \mathrm{LGDP}_{\mathrm{t}} \rightarrow \Delta \mathrm{FI}_{\mathrm{t}}$ & 3.13031 & 0.0864 & $\begin{array}{l}\text { Unidirectional } \\
\text { Causality }\end{array}$ \\
\hline$\Delta \mathrm{LMS}_{\mathrm{t}} \rightarrow \Delta \mathrm{LFDI}_{\mathrm{t}}$ & 5.15575 & 0.03 & $\begin{array}{l}\text { Unidirectional } \\
\text { Causality }\end{array}$ \\
\hline$\Delta \mathrm{LFDI}_{\mathrm{t}} \neq \Delta \mathrm{LMS} 2_{\mathrm{t}}$ & 0.06320 & 0.8031 & No Causality \\
\hline$\Delta \mathrm{LCPI}_{\mathrm{t}} \rightarrow \Delta \mathrm{LFDI}_{\mathrm{t}}$ & 3.47830 & 0.0714 & $\begin{array}{l}\text { Unidirectional } \\
\text { Causality }\end{array}$ \\
\hline$\Delta \mathrm{LFDI}_{\mathrm{t}} \neq \Delta \mathrm{LCPI}_{\mathrm{t}}$ & 0.10637 & 0.7464 & No Causality \\
\hline$\Delta \mathrm{LIP}_{\mathrm{t}} \rightarrow \Delta \mathrm{LMS}_{\mathrm{t}}$ & 5.78204 & 0.0222 & $\begin{array}{l}\text { Unidirectional } \\
\text { Causality }\end{array}$ \\
\hline$\Delta \mathrm{LMS}_{\mathrm{t}} \neq \Delta \mathrm{LIP} \mathrm{P}_{\mathrm{t}}$ & 0.71306 & 0.4047 & No Causality \\
\hline
\end{tabular}

Note: $(1)$ The $(\rightarrow, \leftrightarrow \& \neq)$ represent the unidirectional, bidirectional and no Granger causality respectively. (2) The following variables have been investigated:Logarithm of Price Index Weighted (LPIW); Logarithm of Gross Domestic Product (LGDP); Logarithm of Foreign Direct Investment (LFDI); Logarithm of Money Supply 2 (LMS2); Logarithm of Consumer Price Index (LCPI); Logarithm of Interest Payment on External Payment (LIP); Fuel Import $(\mathrm{FI})$.

Table 2: Causality Analysis for the Amman Stock Exchange (ASE), Model 1 (LPIW).

\section{Granger-causality results for the second model - conventional banking system (CBS)}

The results of the Granger causality analysis for the model of CBS are presented in Table 2. As can be seen from the Table, $\Delta \mathrm{LGDPt}$, 
$\Delta$ LFDIt, $\Delta$ LMS2t and $\Delta$ LCPItGranger causes and lead $\Delta$ LDCt in a unidirectional causality manner. Meanwhile, $\Delta$ LDCthas the leading power towards the $\Delta$ LIPt in a unidirectional way. This implies that the macroeconomic variables have the power to lead and Granger cause the $\triangle \mathrm{LDCt}$. On the other hand, the Granger-causality results among the macroeconomic variables show same results as in the previous discussion for ASE model (see Table 3).

\begin{tabular}{|l|l|l|l|}
\hline Causality Direction & F-Statistic & P-value & Causality Decision \\
\hline$\Delta \mathrm{LGDP}_{\mathrm{t}} \rightarrow \Delta \mathrm{LDC}_{\mathrm{t}}$ & 3.19953 & 0.0278 & Unidirectional Causality \\
\hline$\Delta \mathrm{LDC}_{\mathrm{t}} \neq \Delta \mathrm{LGDP}_{\mathrm{t}}$ & 0.54608 & 0.7394 & No Causality \\
\hline$\Delta \mathrm{LFD}_{\mathrm{t}} \rightarrow \Delta \mathrm{LDC}_{\mathrm{t}}$ & 3.78055 & 0.0607 & Unidirectional Causality \\
\hline$\Delta \mathrm{LDC}_{\mathrm{t}} \neq \Delta \mathrm{LFDI}_{\mathrm{t}}$ & 0.00241 & 0.9611 & No Causality \\
\hline$\Delta \mathrm{LMS}_{\mathrm{t}} \rightarrow \Delta \mathrm{LDC}_{\mathrm{t}}$ & 2.92719 & 0.0968 & Unidirectional Causality \\
\hline$\Delta \mathrm{LDC}_{\mathrm{t}} \neq \Delta \mathrm{LMS}_{\mathrm{t}}$ & 0.26429 & 0.6107 & No Causality \\
\hline$\Delta \mathrm{LCP}_{\mathrm{t}} \rightarrow \Delta \mathrm{LDC}_{\mathrm{t}}$ & 2.36605 & 0.094 & Unidirectional Causality \\
\hline$\Delta \mathrm{LDC}_{\mathrm{t}} \neq \Delta \mathrm{LCPI}_{\mathrm{t}}$ & 1.67216 & 0.1974 & No Causality \\
\hline$\Delta \mathrm{LIP}_{\mathrm{t}} \neq \Delta \mathrm{LDC}_{\mathrm{t}}$ & 1.1199 & 0.2979 & No Causality \\
\hline$\Delta \mathrm{LDC}_{\mathrm{t}} \rightarrow \Delta \mathrm{LIP}_{\mathrm{t}}$ & 6.97865 & 0.0127 & Unidirectional Causality \\
\hline $\mathrm{N}$ &
\end{tabular}

Note: $(1)$ The $(\rightarrow, \leftrightarrow \& \neq)$ represent the unidirectional, bidirectional and no Granger causality respectively. (2) The following variables have been investigated:Logarithm of Domestic Credit (LDC); Logarithm of Gross Domestic Product (LGDP); Logarithm of Foreign Direct Investment (LFDI); Logarithm of Money Supply 2 (LMS2); Logarithm of Consumer Price Index (LCPI); Logarithm of Interest Payment on External Payment (LIP); Fuel Import (FI)

Table 3: Causality analysis for the conventional banking system(CBS), model 2 (LDC).

\section{Granger-causality results for the third model - islamic banking system (ibs)}

Table 4 displays the Granger causality test outcomes for the model of IBS. As suggested by the results, $\triangle \mathrm{LGDPt}$ and $\Delta \mathrm{LMS} 2 \mathrm{tGranger}$ causes $\triangle \mathrm{LMTPOt}$ in a unidirectional manner. Meanwhile, the results also show that the $\triangle$ LCPIt has bidirectional causality with $\triangle$ LMTPOt. The results imply that the Islamic banks follow the economic growth as the $\triangle$ LGDPt Granger cause the $\triangle$ LMTPOt. In addition, the Grangercausality results among the macroeconomic variables show same results as in the previous discussion for ASE model (see Table 4).

\begin{tabular}{|l|l|l|l|}
\hline Causality Direction & F-Statistic & P-value & Causality Decision \\
\hline$\Delta \mathrm{LGDP}_{\mathrm{t}} \rightarrow \Delta \mathrm{LMTPO}_{\mathrm{t}}$ & 9.61694 & 0.0040 & Unidirectional Causality \\
\hline$\Delta \mathrm{LMTPO}_{\mathrm{t}} \neq \Delta \mathrm{LGDP}_{\mathrm{t}}$ & 1.18580 & 0.2843 & No Causality \\
\hline$\Delta \mathrm{LFDI}_{\mathrm{t}} \neq \Delta \mathrm{LMTPO}_{\mathrm{t}}$ & 2.75643 & 0.1066 & No Causality \\
\hline$\Delta \mathrm{LMTPO}_{\mathrm{t}} \neq \Delta \mathrm{LFDI}_{\mathrm{t}}$ & 1.91816 & 0.1756 & No Causality \\
\hline$\Delta \mathrm{LMS}_{\mathrm{t}} \rightarrow \Delta \mathrm{LMTPO}_{\mathrm{t}}$ & 3.87717 & 0.0577 & Unidirectional Causality \\
\hline$\Delta \mathrm{LMTPO}_{\mathrm{t}} \neq \Delta \mathrm{L} \mathrm{MS}_{\mathrm{t}}$ & 0.68049 & 0.4155 & No Causality \\
\hline$\Delta \mathrm{LCPI}_{\mathrm{t}} \rightarrow \Delta \mathrm{LMTPO}_{\mathrm{t}}$ & 3.16462 & 0.0848 & Bidirectional Causality \\
\hline$\Delta \mathrm{LMTPO}_{\mathrm{t}} \rightarrow \Delta \mathrm{LCPI}_{\mathrm{t}}$ & 3.24215 & 0.0812 & \\
\hline
\end{tabular}

Notes: (1) The $(\rightarrow, \leftrightarrow \& \neq)$ represent the unidirectional, bidirectional and no Granger causality respectively. (2) The following variables have been investigated:Logarithm of Murabaha to the Purchase Order (LMTPO); Logarithm of Gross Domestic Product (LGDP); Logarithm of Foreign Direct Investment (LFDI); Logarithm of Money Supply 2 (LMS2); Logarithm of Consumer Price Index (LCPI); Logarithm of Interest Payment on External Payment (LIP); Fuel Import (FI).

Table 4: Causality analysis for the islamic nanking system (IBS), model 3 (LMTPO).

In short, the three models' Granger causality test indicates the existence some of substantial degree of leading power towards other variables such as the economic variables or financial development. The results obtained by this research are in line with the observation of that financial development usually advances together with the economic development, while finance is playing increasingly crucial roles [6]. Further, the discovered causality relationship between macroeconomic variables and Jordan's financial development, the capital and credit markets implies that economic growth leads the financial development of Jordan, not vice versa. As for $\triangle \mathrm{LGDPt}, \Delta \mathrm{LMS} 2 \mathrm{t}$ and $\Delta \mathrm{LCPIt}$, they are found to drive the ASE, CBS and IBS; and are found to possess the power to lead these variables.

In fact, the results of the Granger causality tests demonstrate that the $\mathrm{H} 6$ of the study is accepted for the three models. The results show that the direction of the Granger causality is running from economic growth to Jordan's financial development. However, this study is in line with the first view in the finance-growth nexus theory which posits that financial development is determined by real growth. The findings are consistent with of a number of scholars [7-11].

\section{The Result and Findings}

This study investigates the dynamic relationships in both the shortrun and the long-run, between Jordan's financial development and the macroeconomic variables. Additionally, the study also delves into the relationships for the short run between Jordan's financial development and the global events' variables which make up the dummy variables for the study. For analysis purposes, this study has employed the ARDL approach on the sample gathered from the 1978-2013 period. In particular, this study examined both the short and long-run associations between the financial development of Jordan which is signified by the Amman Stock Exchange (ASE), the conventional Banking System (CBS) and the Islamic Banking System (IBS). Meanwhile, the macroeconomic variables are signified by Gross Domestic Product (GDP), Foreign Direct Investment (FDI), Money Supply (MS2), Consumer Price Index (CPI), Interest Payment on External Debt (IP) and FuelImport (FI,whereas the global events' variables are represented by the September 11, 2001 and Iraqi war (D1), the Global Financial Crisis (D2) and the Arab Spring (D3).To examine data's stationary level, the ADF, PP and KPSS tests have been employed. Meanwhile, for detecting the study variables' number of cointegration, the bounds F-statistic test has been performed. Finally, to examine the causality direction of the variables, the Granger causality test has been conducted.

The main goals of the study are to examine the impact of the macroeconomic variables and the global events' variables on Jordan's financial development in both the short run and the long-run, and to examine the directional causality between Jordan's economy and financial development. The findings are briefly discussed next. 
To achieve the study's objectives, different diagnostic tests have been performed. Based on the results of the diagnostic tests, all models which are the ASE, CBS and IBS, have passed the key diagnostic tests. These tests include the serial correlation, the Ramsey Reset, normality and heteroskedasticity, from which, the correct probability value were attained. The test outcomes confirm the data eligibility for the subsequent step in the analysis. Moreover, the ADF,PP and KPSS tests, which are the unit root tests, have confirmed that at different levels, all variables are stationary whether at $\mathrm{I}(0), \mathrm{I}(1)$ or both. Thus, the application of ARDL approach is suitable.

However, the first objective of this study is to examine the short and long-run relationship between the macroeconomic variables and Jordan's financial development. The bounds F-statistic test has been employed to find the co-integration among the variables. The outcomes of the bound F-statistic test confirm that all models (ASE, CBS and IBS) are co-integrated at different levels. Thus, the application of the ARDL approach is appropriate for examining the equilibrium relationships both in both the short and the long-run. Correspondingly, the optimal lag length was selected based on AIC and HQ criteria's minimum value. As demonstrated by the results, for all models, the suitable lag length is one lag. Furthermore, from the outcomes of the ARDL approach, the ASE and the macroeconomic variables appear to have both the short and long-run equilibrium relationships, and the same is also observed between the ASE and the global events' variables in the short-run.

These results are in support of the theories and the hypothesis of this study which postulates that the ASE is positively affected by GDP, FDIand MS2 but is negatively affected by CPI and IP in the short and the long-run. This demonstrates the effectiveness of all macroeconomic variables for the three models and also, most these variableshave the power to control the ASE, CBS and IBS.

With respect to the second objective which is to examine the impact of global events on Jordan's financial development, the results demonstrate that, the September 11, 2001 and the Iraqi War (D1) and the Arab Spring (D3) show a positive association with the ASE, while the global financial crisis (D2) shows a negative relationship with the ASE, CBS and IBS. The positive impact of the global events, the September 11, 2001 incident, the Iraqi War and the Arab Spring on the ASE can be justified by the migration of cash flows during these events. The cash flows have led to the ASE boom especially in during the September 11, 2001 incident and the Iraqi War in 2001 and 2004-2005 respectively (see Chapter 2). The outcomes obtained for the other two models (the CBS and IBS) also demonstrate consistency with those of the ASE in both the short and long-run equilibrium relationships. However, compared to the other two models, the IBS appears to be less impacted by the global events. Nonetheless, the results for the short and long-run relationships between the ASE, CBS and IBS models' variable are generally in line with the conclusions of other studies [12-14].

According to the GDP model, the obtained results suggest that Jordan's GDP is positively impacted by foreign direct investment (FDI). This indicates that the FDI improves Jordan's GDP particularly in the short-run throughout the September 11, 2001 incident, the Iraqi War and the Arab Spring. Specifically, the September 11, 2001 incident has caused the increase in remittances from Jordanians residing in the United States, while the Iraqi War and the Arab Spring have caused the Iraqi and the Syrian refugees to flock in Jordan and shift their investments into the country. These results are consistent [15].
On the other hand, a positive relationship has also been found between MS2 and GDP. However, a negative relationship was demonstrated with CPI, IP and FI (with respect to the GDP). As for the global events' variables, the GDP is found to be negatively impacted by the Global Financial Crisis (D2). However, the GDP positively affected by the September 11, 2001 and Iraqi war (D1) and the Arab Spring (D3).

For the MS2 model, the results indicate that there is a positive relationship with the GDP, FDI, CPI and FI but show a negative linkage with IP. Increase in MS2 will also increase the prices of goods and services. Meanwhile, the constant price increase signifies the coming of inflation and this is demonstrated by a positive connection between the MS2 and CPI. This is in line with Fisher's (1944) Quantity Theory of Money. The theory basically states that the quantity of money is the main determinant of the price level or the value of money, and any change in the quantity of money produces an exactly proportionate change in the price level.

Regarding the global events variable, the September 11, 2001 incident, the Iraqi War (D1) and the Arab Spring appear (D3) to impart a positive impact on the supply of money. On the other hand, the Global Financial Crisis (D2) is found to negatively affect the money supply.

On other hand, using the ARDL approach, the outcomes on the model of CPI indicate the existence of a negative association between CPI and GDP, FDI and FI. On the other hand, a positive association is demonstrated with MS2 and IP. Further, a positive relationship has been demonstrated by the global events' variables. This implies that the financial crisis and the political events in the neighbouring countries cause the inflation in Jordan to increase.

Based on the ASE, the CBS and the IBS models' error correction terms (ecmt-1), the results appear to be negative and significant. In particular, the values obtained for the three models were $-0.4443 \%$, $-0.5413 \%$ and $-0.4432 \%$, for ASE, CBS and IBS respectively at $1 \%$ significance level with correct signs. Further, the outcomes of the ecmt-1for ASE, CBS and IBS point toward a good speed adjustment back to the equilibrium, are at $44.43 \%, 54.13 \%$ and $44.32 \%$ for ASE, CBS and IBS respectively of the disequilibrium from the preceding year, and returned to equilibrium in the present year.

The third objective of this study is to examine the directional causality between Jordan's economic growth and financial development. The outcomes of the Granger causality test show that a unidirectional causality relationship exists between the ASE and GDP, MS2 and CPI and bidirectional causality with FDI. Also, a unidirectional causality relationship exists between the CBS and GDP, FDI, MS2 and CPI, as well as between ISB, and GDP, MS2and CPI. In the light of the previous results, the outcomes obtained indicate that in Jordan, the economic growth appears to lead and drive the ASE, CBS and IBS. The Amman Stock Exchange and both the conventional and Islamic bank are highly influenced, whether in a positive or a negative way, by most of the macroeconomic variables. The results support observation that the economic growth and financial development are interactively and correspondingly complementing each other.

In general, the main findings are confirming other researcher's studies such as those by who argued that there is a significant relationship between the economic growth and the financial development. 


\section{Conclusion}

The results obtained from the empirical analysis on the three models (ASE, CBS and IBS) were presented and scrutinized in this chapter. In this study, the time series step was employed, starting with the selection of the suitable model after which, the diagnostic tests were performed. Further, three standard unit root tests were employed to check the data stationary. To decide on the lag length, the cointegration test was performed. Next, the ARDL approach was employed to identify the short and long-term relationships between the models' variables. Finally, to ascertain the direction of causality between Jordan's economy and financial development, the Granger causality test was conducted.

Based on the empirical outcomes, it can be deduced that the financial development of Jordan is very much shaped by the macroeconomic variables as well as the global events. However, in terms of the linkages between the financial development and the economic growth in Jordan, the Granger causality test results suggest that real economic activities leads the Jordan's financial development. Finally, from the hypotheses testing, the researcher found consistency between the results obtained with the past theories and empirical studies. The ensuing chapter will summarise the whole study, and then deliberate on the study's contribution and limitation, recommendations and also the policy implications.

\section{Policy Implications and Recommendations}

A number of policy implications, particularly, on the financial development for both the short term and the long term have been derived from the study. The implications would be of interest to the government, the policy-makers and the financial managers in Jordan. The aforesaid policy implications and recommendation are discussed below.

As assessed by the long-term coefficients, the macroeconomic variables play a vital role in dictating the fluctuations of ASE, which lead the capital markets and approximate their performances in Jordan. It can be deduced that the macroeconomic variables are crucial in predicting the performance of Jordan's financial development, and these discoveries are in line with those of people [7-9].

As for the of global events variables results, the result of financial crisis and the political events show that these factors (the financial crisis and the political events) have high impact on the Amman Stock Exchange. Further, with regard to their effect on the banking system, it appears that the conventional banking system is more affected than their Islamic counterpart. In other words, Jordan's Islamic banking system has demonstrated its capability in facing any financial crisis and global events. As such, it is recommended that the policy maker would urge these conventional banks to accommodate the Islamic banking principles in order to reduce the adverse effect of both the financial crises and the political events which occur in the region. Additionally, Jordan's government and policy-makers should promote and encourage the launching of more Islamic financial instruments, establishment of more new Islamic banks and expansion of more branches of banks in Jordan. Accordingly, Jordan's research and development departments should focus more on the Islamic stock market (Islamic stock market is a market which adheres to the Islamic law). Simply put, now is the time for Jordan to shift to the Islamic finance system which is more into instruments of risk-sharing and products that are equity-based. This is in line with the earlier works [12].
Although Jordan has high volume of Foreign Direct Investment, it does not appear to highly affect the country's financial development. This implies that the cash inflow to Jordan particularly from the neighbouring countries which are currently undergoing certain political events goes to the sectors of service and industry. This happens because these investors are unaware of the benefits of investing in the financial market system, and this could be attributed to the fact that these investors' countries are also lacking in the development of the financial development such as the stock market and the Islamic banks when compared to Jordan. Thus, awareness campaigns and programs related to financial markets must be organised by Jordan's government targeted to these Arab investors who may not have the awareness on the financial markets' investments.

As demonstrated by the findings, an increase in GDP and MS2 granger-causes ASE, CBS and IBS. However, the increase in the performance of the ASE, CBS and IBS will improve the growth of Jordan's economy. In accordance with these findings, the respective authority should focus more on finding the efficiency plans to maintain and increase the growth of the GDP and also to support the country's financial development from various perspectives. Further, the study also discovered that MS2 is crucial in the performance of Jordan's financial development. This implies that the ASE, CBS and IBS are impacted by the monetary policy particularly in the long run. Thus, Jordan's Central Bank should have more awareness on this and continues to manage and govern the monetary policy so that it moves in the correct direction. Then, as Jordan's financial development has been found to be affected by the inflation in the short and in the longrun, having monetary policy's management and governance will decrease pressures from inflation.

As demonstrated by this study, the macroeconomic variables' varied effects on Jordan's financial development had significantly affected the performance of Jordan's capital and credit markets. This might be of value for the strategies of portfolio diversification in attaining the best risk-return trade-off, which also implicates that investors could increase the performance of their portfolio in the financial market by paying more attention to the risks of the macroeconomic variables. Thus, from these particular findings of the study, investors from diverse perspectives, the policy perspective for instance, could attain better knowledge on how to develop and implement the economicrelated policies for stabilising the financial markets and increasing the profit gain. Furthermore, by taking advantage of the economic-related information, the investors may be able to make the right investment decision and consequently, attain more profit.

A negative linkage has been demonstrated between the interest payment on external debt and the performance of Jordan's financial development. In particular, increase in IP will decrease the performance in financial development. This is a particularly crucial variable in the context of Jordan due to the country's heavy reliance on money lending from the International Monetary Fund, the United States and also from other Gulf countries in financing the country's needs. Thus, the study recommends that the government employs new policies for reducing the external debt which depends on interest rate. In particular, Jordan could push its saving unit to shift to active investment unit and formulate a strategy for luring more foreign investors particularly from the Arab region into the country. Further, Jordan could also formulate new strategies for dealing with the country's own Islamic banking or with that of other countries such as the Islamic banking form Turkey and Malaysia, rather than depending on the conventional banking to finance its needs. 
As for the Fuel Import (FI), the results found to be clearly positively related with the financial development. This is because, when the quantity of imported fuel is high, the GDP will also increase. In the context of Jordan, GDP leads the Jordan's financial development. Thus, the GDP can help and develop the financial development of the country. Meanwhile, the negative relationship between GDP and FI in the long-run is related to that, Jordan fully import the energy from neighbour countries which make the government pay a large amount form its annual budget to import the country needs from these sources.

However, due to Jordan's four-season climate, the use of fuel would increase during the cold seasons (autumn and winter). Aside from that, transportation services also consume a considerable amount of this fuel. Therefore, new energy sources should be sought to accommodate these usages and reduce the consumption of oil as fuel. Among the alternative energy sources that Jordan's government could consider are the solar and wind energy. Thus, implementing this policy will decrease the country's external debt which is negatively affecting the country's economic growth, particularly, its financial development.

This study also stresses on the importance of the Islamic banking system in Jordan. Thus, efforts should be made by the policy-makers to extend the already available Islamic banks and launch more Islamic banks that employ more Islamic financial instruments such as the Murabaha, the Mudarabah, the Musharakah and the Ijarah. By doing this, money supply could be increased while new jobs opportunities could be created. This will consequently help decrease the problems of poverty and unemployment in Jordan. Aside from that, these banking methods could assist in the reduction of economic difficulties that the country has been facing since the last decades. Thus, the expansion of the Islamic financial system in Jordan could help increase the GDP and improve the economy of the country in general and, in due course, via the increase in the velocity of circulation, the system could increase MS2. Additionally, Jordan's policy-makers should focus more on Islamic finance. This is because the Islamic finance does not rely on interest rate; interest rate could cause financial obstacles and financial obstacles could increase the inflation rate or the financial crisis. In other words, interest rate is the leading cause of financial crises particularly, the global financial crisis which occurred in 2008 [15].

\section{The Contribution and Significant of the Study}

The findings of this study contribute to the expansion of the knowledge in the area of finance. At the same time, some gaps which were found in the literature have also been filled. The key inputs and significance of the study are highlighted below.

Past researchers who explored the impact of macroeconomic variables on the financial development have only looked into the relationship between some of the macroeconomic variables with the stock market and the banking system separately. Meanwhile, researches on the relationships between the macroeconomic variables and those of global events particularly of the new political events on the capital and credit market together, are very limited. On the other hand, this study probed into the relationship between the three forms of Jordan's financial development which are the Amman Stock Exchange, the conventional banking system and the Islamic banking system, the macroeconomic variables and the global events. Thus, aside from enriching the theoretical foundation of the finance domain, this study will be the first to have made comparisons between the effect of the macroeconomic variables on the stock market, the conventional banking system and the Islamic banking system for the period between 1978 and 2013 in Jordan.

New empirical evidences on some macroeconomic variables in the context of Jordan such as Foreign Direct Investment (FDI), Interest Payment on External Debt (IP) and Fuel Import (FI) are presented by this study. Furthermore, as most past studies were focusing on the global financial crisis as the global event variable, this study adds one new variable that is the Arab Spring.

Method-wise, the study employed the bound F-statistic Approach. This model is appropriate when researcher wants to explore the cointegration among the variables. It should be noted that the traditional models such as the Engle Granger and the Johansen and Juselius models were the approach utilised by the past studies. In this study, the ARDL approach was employed to determine the short and long-run relationships between the macroeconomic variables and the global events' variables. Most of the past studies employed the VAR and VECM for determining such linkages. However, compared to the approaches used by the past studies, the ARDL approach used this study is more flexible in analysing the short and long-run situations.

The outcomes of this study could offer the knowledge on how developing countries (in this case, Jordan) suffer from the political unrests that occur in the neighbouring countries. These sufferings are demonstrated in various problems such as poverty, high inflation and unemployment rate, lack of natural resources and high deficit budget. Comparatively, the past studies were only focusing on the developed countries which are not impacted by the latest geo-political events.

This study described the performance of Jordan's financial development during the period of 1978-2013. This is a period that covers several significant global events such as the global financial crisis, the wars and the political events, all of which have affected Jordan's economy. Undeniably, the outcomes generated by this study are of value to Jordan's government, policy-makers as well as finance managers. Thus, perusing this study's outcomes, both the strengths and the weaknesses of Jordan's economy and financial development could be identified. Moreover, based on the recommendations, the respective authorities could make the most appropriate decisions. As such, the right plans and strategies could be implemented. Apart from that, both the local and foreign investors could benefit from this study. This is because this study provides the knowledge on the mutual relationship between the macroeconomic variables and the global events' variables, and Jordan's financial development. As such, by employing this knowledge, investors could formulate their own portfolio to help them gain more from their investments. Apart from that, these investors could also establish more precise asset pricing models and make prediction on the volatility of future stock market. Further, by investigating the global events' variables, the investment situations can be better predicted. Last but not least, researchers in the same field can also use this study as the starting point of their study.

\section{Suggestion for the Future Studies}

This study has provided some knowledge on the relationship between the macroeconomic variables and the financial markets of Jordan, and also the influence of the global events' variables (the September 11, 2001 incident, the Iraqi war, the global financial crisis and the Arab Spring) on the Amman Stock Exchange, the conventional banking system and the Islamic banking system. However, the researcher feels that the outcomes could be better and more 
Citation: Mohammad (2017) Analysing the Short-run and Long-run Relationships between Macroeconomic Variables and Financial Development in Jordan From 1978-2013. J Glob Econ 5: 253. doi:10.4172/2375-4389.1000253

Page 9 of 9

comprehensive if further study could be performed in the areas of economics and finance.

First of all, many macroeconomic variables have been found to impact the financial development of a country particularly in the context of Jordan but a number of these variables have not been addressed in this study. These factors include economic openness, public and private domestic savings, total debt, tax rates, privatization programs and human capital.

Secondly, apart from the global events' variables addressed in this study (which are found to affect the financial development of Jordan), there are also other global events that could also affect Jordan's financial development that this study did not address, for instance, the Asian crisis, particularly, on the performance of Islamic banking.

Thirdly, the results obtained suggest that the FDI in the context of Jordan imparts a significant but small coefficient effect to the ASE and IBS. As such, it is recommended that further study would scrutinise this variable more deeply. In particular, future study could investigate the underlying reason for this variable's such significance of effect. By doing so, it is hoped that the relevant bodies would be able to formulate a strategy for encouraging the foreign investors to bring in more investment to Jordan to enhance the country's financial development.

Fourth, with regard to the Islamic banking system, only the Murabaha method was investigated. As such, probing into the relationship between other Islamic banking methods such as the Musharaka and the Ijarah methods could be of value.

Finally, the causality relationship between the economic growth and financial development appears to be an interesting domain in the context of Jordan. Thus, this area should be examined more deeply. Additionally, the causality relationship between economic growth and insurance sector (conventional and Islamic), mutual funds and Sukuk is also another area that should be examined.

\section{References}

1. Bekhet HA, Matar A (2013) The Twelfth Scientific Annual International Conference for Business. Human Capital in a Knowledge Economy, pp: 22-25

2. Bettin G, Zazzaro A (2012) "Remittances and Financial Development: Substitutes or Complements in Economic Growth?". Bulletin of Economic 4: 509-536.

3. Odhiambo N (2010) 'Finance-investment-growth nexus in South Africa: an ARDL-bounds testing procedure'. Econ. Chang 43: 205-219.

4. Kim DD, Seo J (2003) 'Does FDI inflow crowd out domestic investment in Korea?'. Journal of Economic Studies 30: 605-622.

5. Dickey DA, Fuller WA (2012) Distribution of the estimators for autoregressive time series with a unit root. Journal of the American Statistical Association 74: 427-431.

6. Mishkin F (1995) Symposium on the Monetary Transmission Mechanism. Journal of Economic Perspectives 9: 3-10.

7. Beck T, Levine R (2002) Industry growth and capital allocation: does having a market or bank-based system matter?. Journal of Financial Economics 64: 147-80.

8. Mundaca BG (2009) Remittances, Financial Market Development, and Economic Growth: The Case of Latin America and the Caribbean. Review of Development Economics 2: 288-303.

9. William M H (2011) Price Outlook and Volatility in Global Grain Markets: Policies and Other Factors. Astana Economic Forum.

10. Pavy JJ, Denekamp J, Letschert J (1995) Late effects toxicity scoring: the SOMA scale. Radiother Oncol 35:11-15

11. Flamini G, Cioni PL, MorelliI, Bader A (2007) Food Chem.100:1- 732.

12. C Vaze, M Varanasi (2008) Dirty paper coding for fading channels with partial transmitter side information. Systems and Computers, pp: 341-345.

13. Zahouania H, Mezghani S, Paillermattei C (2009) Effect of roughness scale on contact stiffness between solids. Wear 266: 589-591.

14. Akotey JO, Osei KA, Gemegah A (2011) The demand for micro insurance in Ghana. The Journal of Risk Finance 12:182-194.

15. Binagwaho A, Hartwig R, Ingeri D, Makaka A (2012) Mutual Health Insurance and its Contribution to Improving Child Health in Rwanda, pp:66-12. 